\title{
強度のばらつきを考慮した座屈拘束ブレースの接合部耐力要求值 DEMAND OF STRENGTH FOR CONNECTIONS OF BUCKLING-RESTRAINED BRACES CONSIDERING VARIATION OF MECHANICAL PROPERTIES
}

\author{
久米建 一 ${ }^{*}$, 吹田 啓一郎**, 佐 藤 篤 司 ${ }^{* * *}$ \\ Kenichi KUME, Keiichiro SUITA and Atsushi SATO
}

\begin{abstract}
Seismic response of the passive controlled structure using buckling-restrained braces (BRB) can be ensured when the BRB connection have sufficient strength. Therefore, it is necessary to prevent the occurrence of slippage or yielding at the connections. In this paper, parametric seismic response analysis was conducted to clarify main factors concerning strength of connections that will affect seismic response of structures. In the analysis, strength variations of BRB and bolted connection are considered. Finally, in order to ensure performance of passive controlled structures and decrease damage of frames, the methodology to determine the demand of strength for connections is revealed.
\end{abstract}

Keywords : Buckling-Restrained Braces, Connection Factor, High Strength Bolt Connection variation of mechanical properties, Earthquake Response Analysis 座屈拘束ブレース, 接合部係数, 高力ボルト接合, 強度のばらつき, 地震応答解析

\section{1. はじめに}

制振構造では，主体骨組にエネルギー吸収を目的とした座屈拘束 ブレース (Buckling-Restrained Braces，以下 BRB) などの制振部材を 取り付けて地震時の応答低減を図っている. BRB 芯材は地震時には 繰り返し応力による歪硬化で応力上昇するため，接合部には BRB 降 伏時よりも大きな軸力が作用することになる．BRBは一般に高力ボ ルト摩擦接合によって主体骨組に接合されるが，接合部にすべりや 降伏が生じると, 期待する制振性能を発揮できない場合があるため, 接合部の破断防止を目的とする耐震ブレースの接合部設計方法 ${ }^{1)}$ そのまま BRB 接合部に用いることはできない，BRB の制振性能を 十分に発揮させるための設計資料 ${ }^{2) ~ 4)}$ は種々刊行されているが，接 合部に必要な耐力は未だ定量的に示されていない. 現状では耐力の 足りない接合部を用いて制振効果を発揮できなかったり，逆に不必 要に耐力の高い接合部を用いて経済的に不利な設計となりうる。本 研究ではこのような問題を回避して BRB の制振効果を確保するため の接合部耐力の必要值の決定法を検討寸る. 接合部必要降伏耐力 ${ }_{j} N_{y}$ は接合部係数 ${ }_{j} \alpha$ を用いて (1) 式により定義する.

$$
{ }_{j} N_{y} \geq{ }_{j} \alpha \cdot N_{y}
$$

ここで $N_{y}$ は BRB の降伏軸力を表す.

本研究では BRB と接合部の耐力が変動することを鋼材，接合部の 実データに基づいて統計的に考慮し，制振効果が十分に発揮される 条件を明らかにするために地震応答解析を行う。また，構造物の固 有周期，構造特性係数，BRB の耐力，フレームとの剛性比や歪硬化 係数などの構造物のパラメータを変えることで, 接合部係数を決定 する際にどの因子が大きく影響するかを分析する，その結果を元に， 制振構造に利用される BRB 接合部の接合部係数 ${ }_{j} \alpha$ の決定法を検討 した.

\section{2. 解析方法}

\subsection{1 質点系モデルの設定}

1. で述べたように，接合部係数を決定する際には様々な影響因子 が想定できる，そこで本研究では様々な条件が混在せずに，特定の 条件の組み合わせ下での応答を個々に明らかにするため, BRB 付骨 組を図 1 のように 1 質点系にモデル化して, 地震応答解析を行った.
* 京都大学大学院建築学専攻 修士課程

** 京都大学大学院建築学専攻 教授・博士 (工学)

*** 名古屋工業大学大学院創成シミュレーション工学専攻 准教授·博士 (工学)
Graduate Student, Dept. of Architecture and Architectural Engineering, Kyoto Univ. Prof., Dept. of Architecture and Architectural Engineering, Kyoto Univ., Dr. Eng. Assoc. Prof., Dept. of Scientific and Engineering Simulation, Nagoya Institute of Technology, Dr. Eng. 


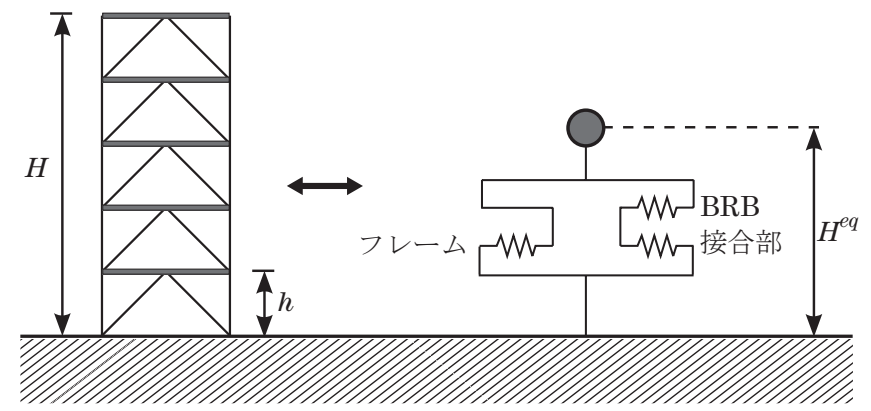

図 1 1質点系モデルと多層骨組の関係

したがって, フレーム, BRB は全ての層で同一の挙動をするものと して扱っており, BRB の配置が層によって異なる場合や高次モード, 架構の曲げ変形の影響は考慮していない.

まず最初に構造物の固有周期 $T$ と剛性比 $k\left(=K_{D} / K_{F}, K_{D}: \mathrm{BRB}\right.$ の 剛性, $K_{F}$ : フレームの剛性) を設定する. 構造物の重量は $W(\mathrm{~N})$ と し, 質量 $m$ は $W / g(g$ は重力加速度) となる. 構造物の高さ $H$ は $T=0.03 H$ の式を元に固有周期から逆算し, 各層の質量が等しいもの と仮定して構造物の等価高さ $H^{e q}$ を(2) 式により算定する ${ }^{5)}$.

$$
H^{e q}=\sqrt{\frac{(N+1)(2 N+1)}{6 N^{2}}} H
$$

この值により構造物の変形角を計算する，階高 $h$ を設定すると層数 $N$ も求められる. フレームと BRB の復元力特性はバイリニア型とし, 系全体ではトリリニア型とする. 解析においてはフレームの歪硬化 係数 $\kappa_{F}, \mathrm{BRB}$ の歪硬化係数 $\kappa_{D}$ を考慮するが，構造物の設計時には フレーム，BRB とも図 2 のように完全弾塑性として設計する. BRB は全て同一の挙動をするものとして扱う. フレームと BRB を合わせ た系全体の剛性を $K_{T}$ とすると， $K_{T}$ は (3) 式によって求められる.

$$
K_{T}=m \omega^{2}=\frac{4 \pi^{2}}{g T^{2}} W
$$

この值と $k$ を元に $K_{F}$ と $K_{D}$ を計算することができる.さらに，地震 地域係数 $Z$, 振動特性係数 $R_{t}, 1$ 次設計用の層せん断力係数 ${ }_{1} C_{0}, 2$ 次設計用の層せん断力係数 ${ }_{2} C_{0}$, 構造特性係数 $D_{S}$ とすると 1 次, 2 次の必要な水平耐力 $Q_{1}, Q_{2}$ は (4), (5) 式によって得られる.

$$
\begin{aligned}
& Q_{1}=Z \cdot R_{t} \cdot{ }_{1} C_{0} \cdot W \\
& Q_{2}=D_{S} \cdot Z \cdot R_{t} \cdot{ }_{2} C_{0} \cdot W
\end{aligned}
$$

これらと図 2 の関係から計算すると $Q_{F y}$ と $Q_{D y}$ が $\mu_{1}=\left(\delta_{1} / \delta_{D y}\right)$ を用い て(6)，(7)式のように表せる.

$$
\begin{aligned}
Q_{F y} & =Q_{2}-\frac{K_{D}}{K_{D}+\mu_{1} K_{F}} Q_{1} \\
Q_{D y} & =\frac{K_{D}}{K_{D}+\mu_{1} K_{F}} Q_{1}
\end{aligned}
$$

以上のような手順で復元力特性の各值を決定する.

\section{2 高カボルト摩擦接合部のモデル化}

BRB は図 3 のようにフレームに溶接されたガセットプレートと添 板を介して接合される場合を想定する. 摩擦接合部はすべりで降伏 耐力が決まる設計とする. 高力ボルト摩擦接合部のすべり耐力 $Q_{J y}$ に達するまでは剛とし, ボルトクリアランスによるすべりが生じた 後は高力ボルトが支圧状態になり, 一定の剛性を保つ. 接合部のボ ルト孔はボルト軸径に対して両側 $1 \mathrm{~mm}$ のクリアランスがあると仮 定し,ボルト接合部 1 カ所につき $2 \mathrm{~mm}$ の寸べりが生じると仮定した.

\begin{tabular}{ll|}
$Q:$ 層せん断力 & $\delta:$ 水平変形 \\
$Q_{F y}:$ フレーム降伏時の耐力 & $\delta_{F y}:$ フレーム降伏時の水平変位 \\
$Q_{D y}: \mathrm{BRB}$ 降伏時の耐力 & $\delta_{D y}: \mathrm{BRB}$ 降伏時の水平変位 \\
$Q_{J y}:$ 接合部すべり時の耐力 & $\delta_{1}: 1$ 次設計レベルの水平変位 \\
$Q_{1}: 1$ 次設計レベルの耐力 & $\delta_{\mathrm{s}}:$ 接合部のすベりによる水平変位 \\
$Q_{2}: 2$ 次設計レベルの耐力 & $\theta: \mathrm{BRB}$ の設置角度
\end{tabular}

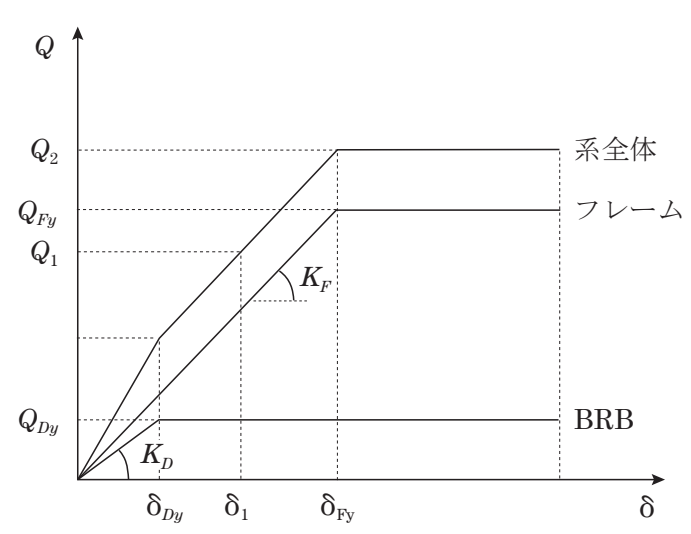

図 2 フレーム, $\mathrm{BRB}$ の $Q-\delta$ 関係の設計における設定
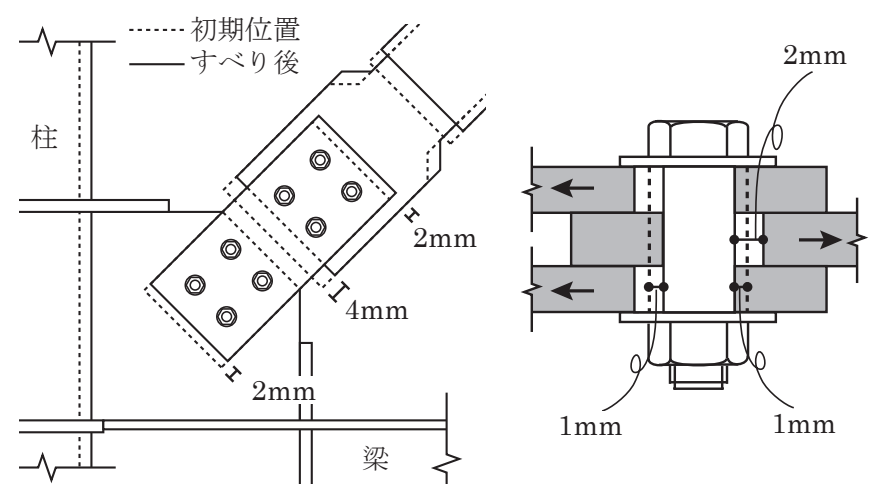

図 3 接合部の詳細例とすべり距離

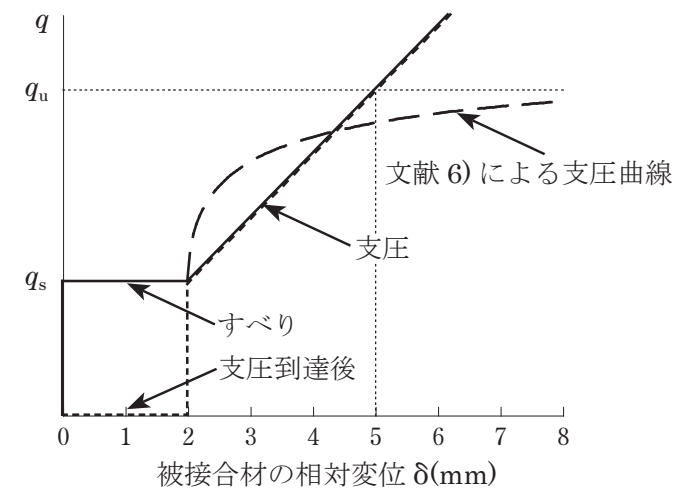

図4 高力ボルト摩擦接合部の荷重-相対変位関係 (ボルト 1 本あたり)

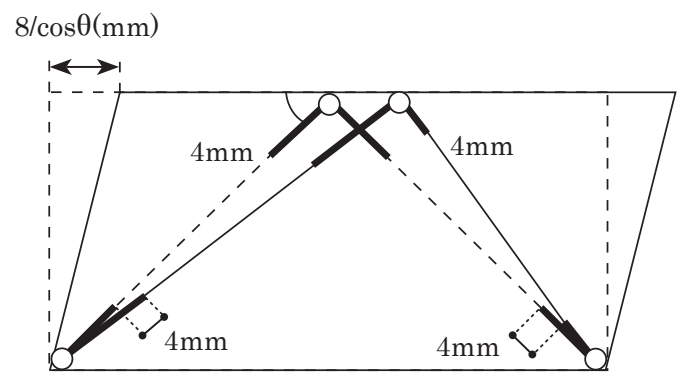

図 5 接合部のすべりと層間変位の関係 
表 1 構造物の各諸量 $\left(D_{S}=0.35, \mu_{1}=2\right)$

\begin{tabular}{|c|c|c|c|c|c|c|c|c|c|}
\hline モデル & 0604 & 0607 & 0610 & 1204 & 1207 & 1210 & 1804 & 1807 & 1810 \\
\hline 固有周期 $T(\mathrm{~s})$ & 0.6 & 0.6 & 0.6 & 1.2 & 1.2 & 1.2 & 1.8 & 1.8 & 1.8 \\
\hline 剛性比 $k$ & 0.4 & 0.7 & 1.0 & 0.4 & 0.7 & 1.0 & 0.4 & 0.7 & 1.0 \\
\hline 高さ $H(\mathrm{~m})$ & 20 & 20 & 20 & 40 & 40 & 40 & 60 & 60 & 60 \\
\hline 層数 $N$ & 5 & 5 & 5 & 10 & 10 & 10 & 15 & 15 & 15 \\
\hline 等価高さ $H^{e q}(\mathrm{~m})$ & 13.3 & 13.3 & 13.3 & 24.8 & 24.8 & 24.8 & 36.4 & 36.4 & 36.4 \\
\hline フレーム剛性 $K_{F} / W\left(\mathrm{~m}^{-1}\right)$ & 7.99 & 6.58 & 5.60 & 2.00 & 1.65 & 1.40 & 0.888 & 0.731 & 0.622 \\
\hline BRB 剛性 $K_{D} / W\left(\mathrm{~m}^{-1}\right)$ & 3.20 & 4.61 & 5.60 & 0.80 & 1.15 & 1.40 & 0.355 & 0.512 & 0.622 \\
\hline BRB 降伏耐力 $Q_{D_{2}} / W$ & 0.0334 & 0.0519 & 0.0667 & 0.0278 & 0.0431 & 0.0556 & 0.0185 & 0.0288 & 0.0370 \\
\hline フレーム降伏耐力 $Q_{F y} / W$ & 0.317 & 0.298 & 0.283 & 0.264 & 0.249 & 0.236 & 0.176 & 0.166 & 0.157 \\
\hline すべり距離 $\delta_{s}(\mathrm{~m})$ & 0.0376 & 0.0376 & 0.0376 & 0.0701 & 0.0701 & 0.0701 & 0.103 & 0.103 & 0.103 \\
\hline
\end{tabular}

また，支圧後のせん断力と変形の関係については，ボルトが 1 本の 場合の実験式である (8) 式の指数曲線 ${ }^{6}$ をを参考に仮定した.

$$
q_{b}=q_{u}\{1-\exp (-10 \times(\delta-2) / 25.4)\}^{0.55} \quad \text { (8) }
$$

ここで $q_{b}$ は支圧による接合部のせん断力， $q_{u}$ は支圧による接合部の 最大耐力, $\delta$ は接合される 2 枚の鋼板の相対変位 $(\mathrm{mm})$ である. 寸 べりによる変位を $2 \mathrm{~mm}$ としているため, 鋼板の支圧による局所変 形は $\delta-2(\mathrm{~mm})$ である. 具体的には, $q_{u}$ の值が高力ボルトのせん断 耐力と等しいものと仮定し, 支圧による局所変形 $\delta-2$ が $3 \mathrm{~mm}$ に達 したときにちょうど $q_{u}$ に達するものとして直線に置き換えた．この ようにして設定したボルト 1 本あたりの接合部の荷重一変形関係を図 4 に示す. $q$ はボルト 1 本あたりにかかるせん断力, $q_{s}$ はボルト 1 本 あたりのすべり耐力である.

実際の接合部ではす心゙りが発生する前や支圧の進行時に鋼材が有 効断面降伏して複雑な挙動となることも考えられるが，この仮定に おいては，接合部の鋼材の降伏が先行しないように十分な降伏耐力 を与えられているものとして降伏することは考慮していない，また， 一度高力ボルトが支圧状態になったあとはボルト張力が抜けてすべ り耐力が 0 になると仮定する. 寸なわち, 図 4 の破線の挙動を示し, 支圧変形に伴ってす心゙り量も増加する. 支圧到達後のす心゙り耐力は, 例えば辻岡による高力ボルト摩擦接合部の実験 7 ではすべり耐力を 5 割以上維持し, 加振周波数, 鋼材の降伏によってはすべり耐力が 増加することがわかっているが, 本研究では支圧到達後にエネルギー 吸収が無く最も制振性能に悪影響を及ぼす場合を想定した。また, すべての高力ボルト接合部に同時にすべりが発生するものとすると, 図 3 のようにガセットプレートと添板, BRB 芯材と添板の間でそ れぞれ $2 \mathrm{~mm}$ ずつ合計 $4 \mathrm{~mm}$ のすべりが発生する. これによる変形 は図 5 のようにブレース両端において生じるため, ブレース 1 本に つき軸方向に $8 \mathrm{~mm}$ の変形に相当する. 対応する層間変形は各層 81 $\cos \theta(\mathrm{mm})$ である.これに等価高さを乗じて水平変位を算出し， 1 質 点系全体の接合部の荷重一変形関係を設定した.

\section{3 パラメータの設定}

$2.1 ， 2.2$ 節の手順で構造物を設計する際の各パラメータを設定す る. まず固有周期 $T$ は中層から高層を想定し $0.6,1.2,1.8(\mathrm{~s})$ の 3 通り, 剛性比 $k$ は $0.4,0.7,1.0$ の 3 通りとし, これらの組み合わ せで計 9 通りをモデル化する. 構造特性係数 $D_{S}$ は実際の建物に近い 值として 0.35 を用い，このレベルに達したときにちょうどフレーム が塑性化するものとしている. エネルギー法によれば，BRB は 1 次
設計レベルの層せん断力よりも小さな荷重で塑性化させることが認 められているため ${ }^{8)}, 1$ 次レベルの層せん断力が静的に作用した際に BRB の塑性率 $\mu_{1}\left(=\delta_{1} / \delta_{D y}\right)$ が 2 となるように設定した。 BRB の歪硬 化係数は座屈拘束方法等により異なるが文献 8) の技術データを元に $\kappa_{D}=3 \%$ とする. なお， $D_{S}, \mu_{1}, \kappa_{D}$ についてはこれらの值を变更し た場合の影響も後に考察する.地震波には BCJ-L2 の原波の他, 最 大速度を $50 \mathrm{~cm} / \mathrm{s}$ で基準化した標準 3 波 (El-Centro-NS, Taft-EW, Hachinohe-NS) でも解析を行う.

また，以下の值はすべての解析で同一の值とした， $Z=1.0$, ${ }_{1} C_{0}=0.2,{ }_{2} C_{0}=1.0, R_{t}=\{1(T \leqq 1), 1 / T(T>1)\}, \kappa_{F}=2 \%, h=4 \mathrm{~m}, \theta=45$ 度, 減衰定数 $2 \%$. これらの值を元に設計した 9 モデルの各諸量を表 1 に示す.フレーム, BRB の剛性と降伏耐力については $W$ で無次元 化した值としている．地震応答解析は, Newmark $\beta$ 法 $(\beta=1 / 4)$ を用 いて行い, 減衰は初期剛性比例型とした。

\section{4 鋼材と接合部の強度統計值と解析上の設定}

耐震設計においては降伏耐力等がばらつく場合も下限值のみを考 えて設計される場合が多い.しかし，制振部材の場合，設計と実勢 值の違いが建物の応答に影響を及ぼすと考えられる。そのため解析 モデルの復元力特性に鋼材と接合部の耐力のばらつきを次のように 考慮して BRB の降伏耐力 $Q_{D y}$, 高力ボルト接合部の寸べり耐力 $Q_{J y}$ の值を設定し，地震応答解析を繰り返し行い統計的に考察する．た だし, フレームの降伏耐力 $Q_{F y}$ は規格下限值で一定であるものとし, ばらつきは設定していない.

(1)BRB の降伏耐力 $Q_{D y}$ のばらつき

芯材鋼種は SN400B，LY225 の 2 種とし，（7）式で決まる BRB 降 伏時の水平耐力 $Q_{D y}$ はそれぞれ表 2 の設計值に示寸降伏応力に基づ いて定められている. この $Q_{D y}$ に鋼材の降伏応力の統計值に基づく 正規分布とみなして発生させた乱数によって定まる降伏応力と表 2 の設計值の比を乗ずることにより，BRB 降伏耐力のばらつきを考慮 した $Q_{D y}$ を定める. $\mathrm{SN} 400 \mathrm{~B}$ は日本鉄鋼連盟によって行われた志村 らの調查 ${ }^{9)}$ による統計值を用いた。 LY225 は日本建築学会大会梗概 集に発表された 1994 年から 2007 年までの 79 個の実験值を用いて 算出した統計值を用いた。 これらの統計值は表 2 に示している.こ の統計值を元に作成した乱数の分布を図 6 に示寸. 曲線で示してい る部分が統計值に基づく正規分布，棒グラフが作成したデータであ る。ただし，鋼材規格の下限值と上限值を外れるものは解析から除 いた. 
表 2 BRB 芯材の降伏応力の統計值

\begin{tabular}{|c|c|c|c|c|c|}
\hline 鋼材 & $\begin{array}{c}\text { 設計值 } \\
\left(\mathrm{N} / \mathrm{mm}^{2}\right)\end{array}$ & $\begin{array}{c}\text { 規格下限値 } \\
\left(\mathrm{N} / \mathrm{mm}^{2}\right)\end{array}$ & $\begin{array}{c}\text { 規格上限値 } \\
\left(\mathrm{N} / \mathrm{mm}^{2}\right)\end{array}$ & $\begin{array}{c}\text { 平均値 } \\
\left(\mathrm{N} / \mathrm{mm}^{2}\right)\end{array}$ & 標準偏差 \\
\hline $\mathrm{SN} 400 \mathrm{~B}$ & 235 & 235 & 355 & 295 & 18.7 \\
\hline LY225 & 205 & 205 & 245 & 225 & 11.0 \\
\hline
\end{tabular}

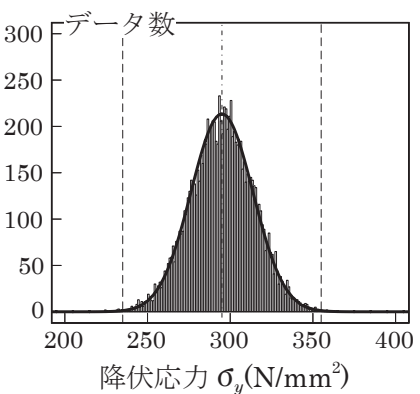

(a) $\mathrm{SN} 400 \mathrm{~B}$

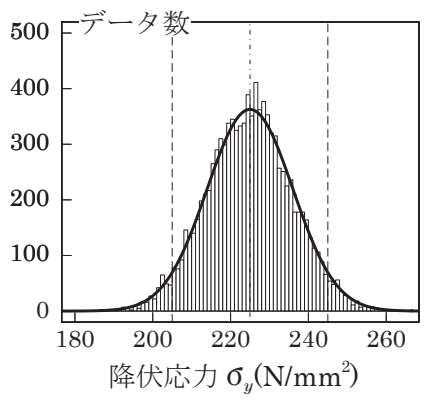

(b)LY225
図 6 BRB 鋼材の降伏応力（作成した乱数の分布）
表 3 接合部のすべり係数の統計值

\begin{tabular}{|c|c|c|c|}
\hline 摩擦面処理 & 設計值 & 平均值 & 標準偏差 \\
\hline ブラスト & 0.450 & 0.560 & 0.0763 \\
\hline 赤錆 & 0.450 & 0.609 & 0.0530 \\
\hline
\end{tabular}

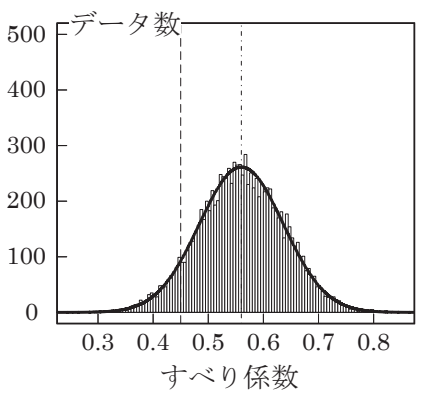

(a)ブラスト

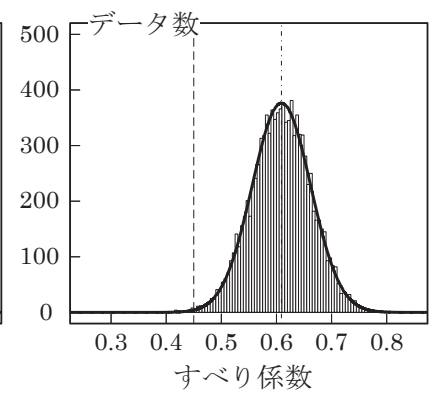

(b) 赤錆

図 7 BRB 接合部の寸べり係数（作成した乱数の分布）

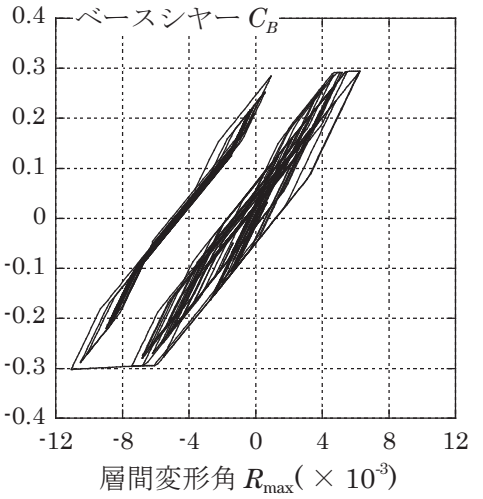

(a) 全体の挙動

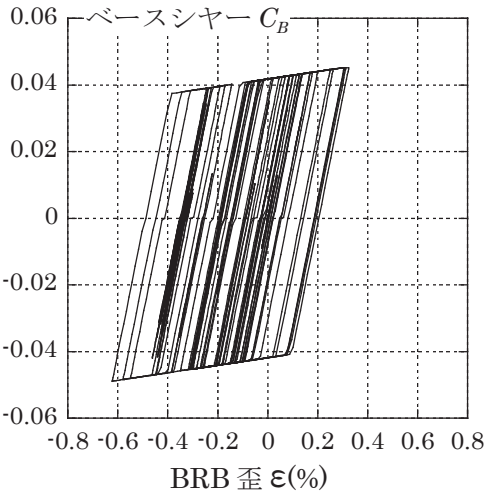

(b) $\mathrm{BRB}$ の挙動

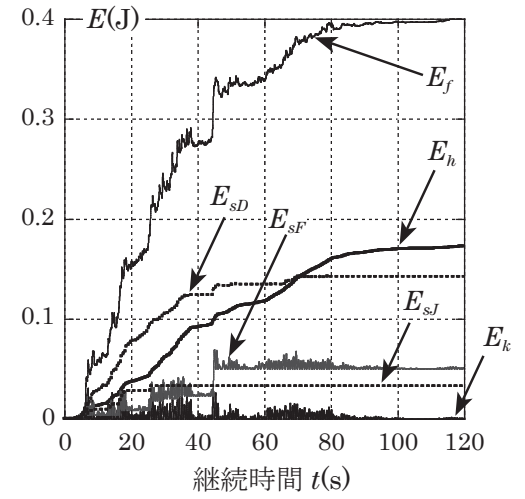

(c) エネルギー応答の時刻歴

図 8 地震応答解析の結果例

(2) 高力ボルト接合部の寸べり耐力 $Q_{J y}$ のばらつき

高力ボルト接合部の寸べり耐力は，（7）式による $Q_{D y}$ に，そのモデ ルに設定した接合部係数を乗じた值が基本となり，これはすべり係 数 0.45 で得られるすべり耐力 $Q_{J y}$ である. この $Q_{J y}$ のばらつきにつ いてもすべり係数の統計值を元に乱数発生させたデータを用いる. ボルト張力は一定であるとし，すべり耐力はすべり係数のばらつき によって決定されるものとする。摩擦面処理がブラストの場合と赤 錆の場合を想定し, ブラストの場合は高力ボルト協会技術分科会に よる統計值 ${ }^{10 ）}$ ，赤錆の場合は文献 11）の統計值に基づいて乱数発生 させた. 表 3 にすべり係数の統計值, 図 7 にその分布を示す.

\section{3. 地震応答解析結果}

\section{1 解析結果の例}

まず，接合部にすべりが生じる場合の一例として耐力の統計的ば らつきを考慮せずに行った解析結果を示す．図 8 は $T=1.2, k=0.7$ で $\mathrm{BRB}$ の降伏耐力の実勢值が設計值と等しいとした場合の結果であ る. $\mu_{1}=2, D_{S}=0.35, \kappa_{F}=2 \%, \kappa_{D}=3 \%$ とし, 地震波は BCJ-L2 の原 波を用いた。接合部の寸心゙り耐力は BRB 降伏耐力の 1.05 倍と低め に設定しており，BRBが降伏し，歪硬化の影響で耐力上昇すること により接合部にす心゙りが生じや寸い条件となっている。図 8(a) は全
体の挙動を示している. 構造物の最大層間変形角は 100 分の 1 をや や超えた值となっている. 図 8(b) はBRBのみの挙動を示しており, この解析では最大歪は $0.6 \%$ 程度である. 図 $8(\mathrm{c})$ において $E_{f}$ は地震 による入力エネルギー， $E_{h}$ は減衰によるエネルギー， $E_{k}$ は運動エネ ルギー， $E_{s F}, E_{s D}, E_{s . J}$ はそれぞれフレーム， $\mathrm{BRB}$ ，接合部の吸収エネ ルギーである。これらは $W$ が $1(\mathrm{~N})$ とした場合の值であり，実際の 建物の場合この值に重量 $W$ を乗ずる必要がある，エネルギー吸収を 見るとフレームの塑性化により $E_{s F}$ が急増していることや, 接合部 にす心゙りが生じ $E_{s, J}$ が発生していることがわかる.

\section{2 鋼材強度, すべり係数のばらつきの影響}

3.1 の解析にばらつきを考慮して繰り返し計算した一例として $T=1.2, k=0.7$ の結果を図 9 に示寸. BRB には SN400B を用い, 接 合部の摩擦面はブラスト処理を仮定した。また，ばらつきの影響が 現れやすい条件とするために接合部係数はやや小さめの 1.20 として 設計している．図 9 の横軸は統計に基づいて発生させた個々のモデ ルの BRBの降伏応力 $\sigma_{y}$ で，(a) 一 (c) の縦軸はそれぞれ層間変形角 $R_{\text {max }}$, 損傷に寄与するエネルギー $E_{d m}$ に対する $E_{s F}$ の比, $E_{d m}$ に対す る $E_{s D}$ の比である.ひとつの図に 1 万通りの点がプロットされている. (a)の図の線状に見える部分は接合部にす心゙りが生じていない場合の 結果が集合している部分であり，層間変形角は 100 分の 1 程度に抑 


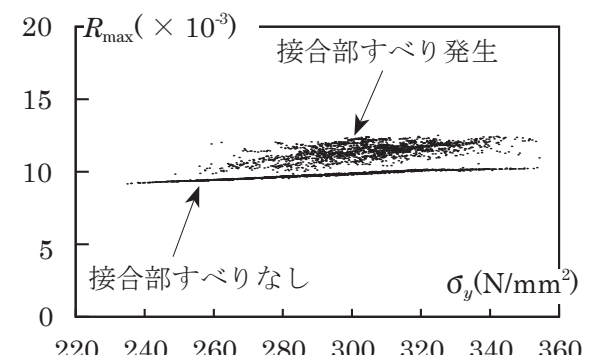

(a) 最大層間変形角

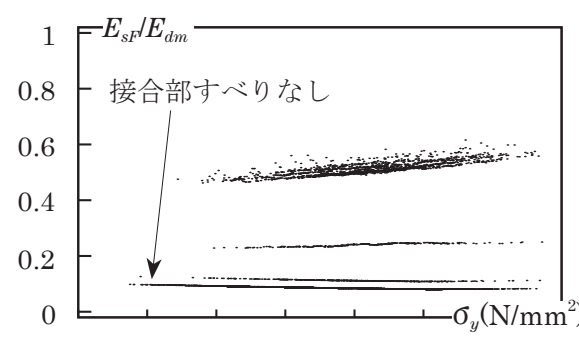

$\begin{array}{llllllll}220 & 240 & 260 & 280 & 300 & 320 & 340 & 360\end{array}$ (b) フレームのエネルギー吸収

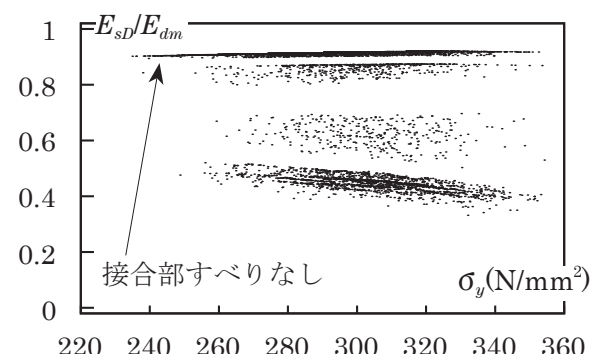

(c) BRBのエネルギー吸収

図 9 ばらつきの影響（ $\mathrm{T}=1.2, \mathrm{k}=0.7, \mathrm{DS}=0.35$, 歪硬化係数 $3 \%, \mathrm{BRB}$ 早期降伏 $(1$ 次レベルで塑性率 2$)$, 摩擦面処理ブラスト )

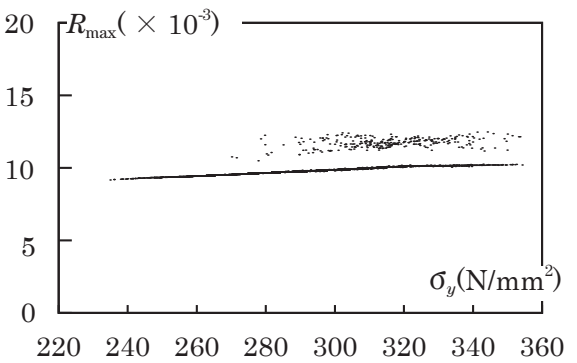

（a）最大層間変形角

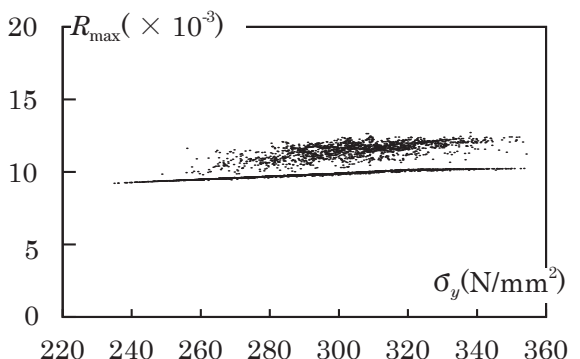

(a) 最大層間変形角

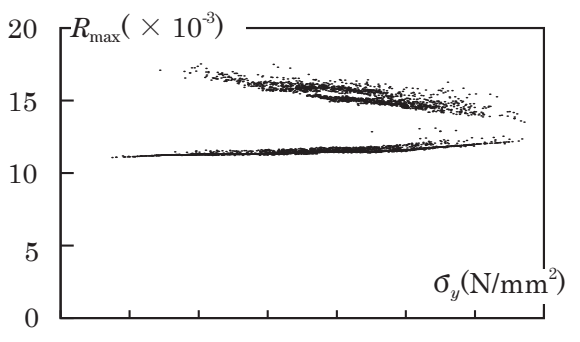

（a）最大層間変形角

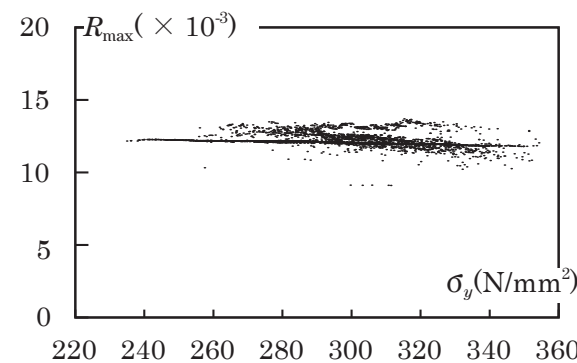

(a) 最大層間変形角

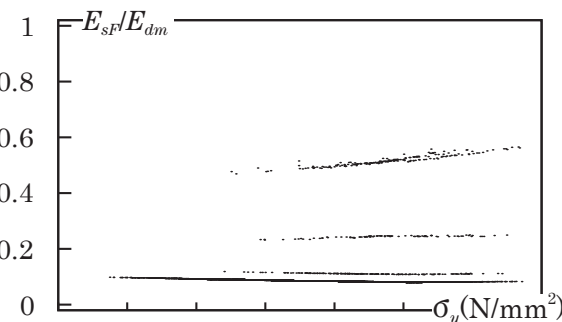

$\begin{array}{llllllll}220 & 240 & 260 & 280 & 300 & 320 & 340 & 360\end{array}$

(b) フレームのエネルギー吸収

図 10 摩擦面処理を赤錆とした場合

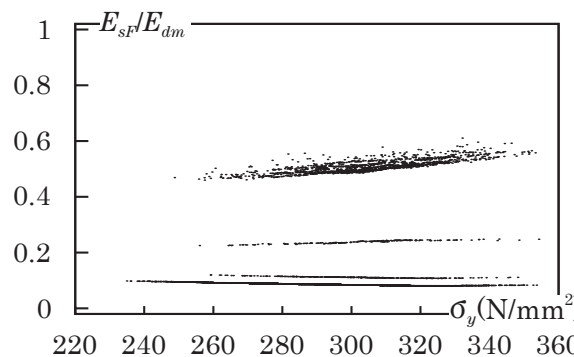

(b) フレームのエネルギー吸収

図 $11 \mathrm{BRB}$ の歪硬化係数を $2 \%$ とした場合

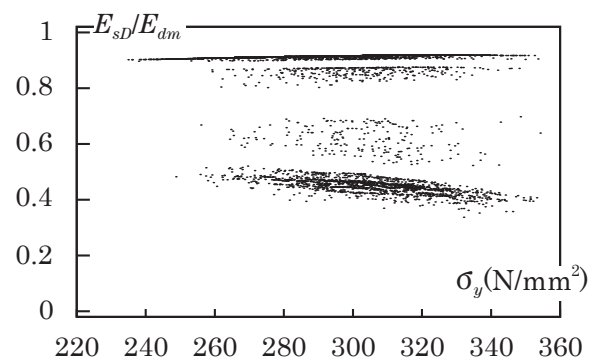

(c) BRBのエネルギ一吸収

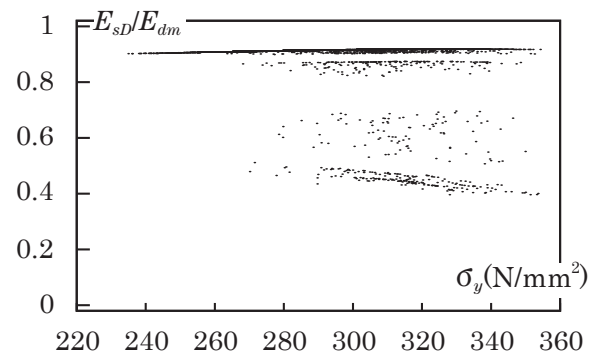

(c) BRBのエネルギー吸収

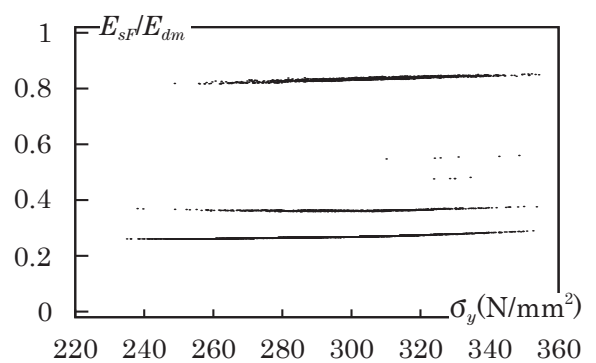

(b) フレームのエネルギー吸収

図 $12 \mathrm{D}_{S}=0.25$ とした場合

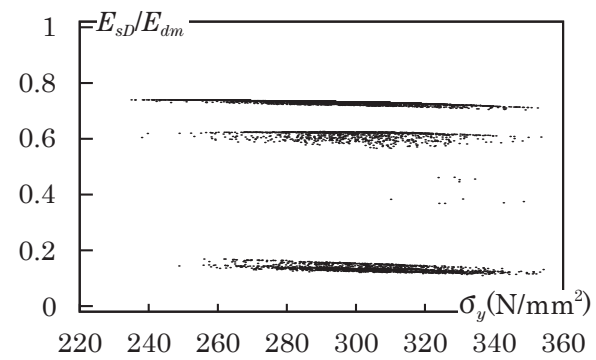

(c) BRB のエネルギー吸収

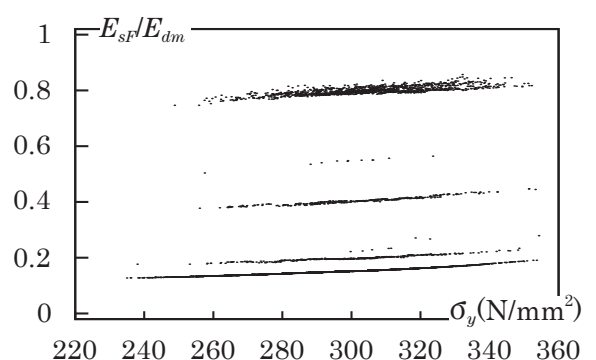

(b) フレームのエネルギー吸収

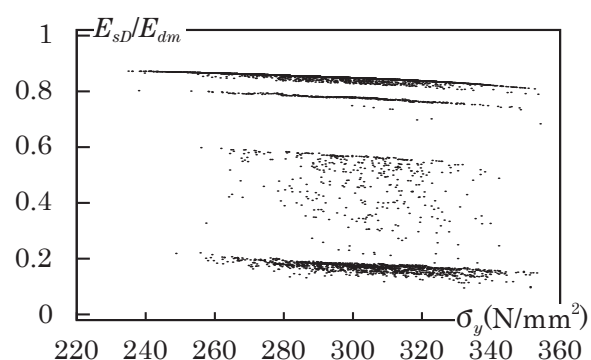

(c) BRBのエネルギー吸収

図13 BRB を1次レベルまで弾性に保つ設計とした場合 
えられている，一方，ばらついた点は接合部にすべりが生じた場合 であり，このとき層間変形角は 2 割程度大きくなっているのがわか る. 解析を行った 1 万通りの内, $36.1 \%$ の場合において接合部にす べりが生じている．接合部にすべりが生じることで $E_{s D}$ が小さくな り, その結果, $E_{S F}$ が大きくなり, 応答も 2 割程度大きくなっている. 地震波を入力してから接合部が支圧に達するまでの時間によって図 9(b)，(c)のように点がいくつかの部分にまとまって現れる．応答に 関しては固有周期と地震波のスペクトルの影響が大きいため, 固有 周期と剛性比の異なるモデルでは接合部に損傷が生じない場合の応 答の大きさやすべりが発生した際の悪化の度合いにやや差が見られ た。一方，エネルギー吸収に関しては他のモデルにおいてもほぼ同 様の結果となっている.

\section{3 各パラメータが及ぼす影響}

\subsection{1 摩擦面処理の影響}

3.2 の解析の条件で，摩擦面処理のみを赤錆に変えた場合を検討寸 る.結果を図 10 に示す，赤錆の場合はブラストの場合よりもす心゙り 係数が全体に大きくなり接合部にす心゙りが生じる可能性は小さくな る。す心゙りが発生する確率は $9.3 \%$ であった。す心゙りが生じた場合 の変形やエネルギー吸収の悪化の度合いはブラストの場合と同程度 である。

\section{3. 2 歪硬化係数の影響}

3.2 の解析で BRB の歪硬化係数の值を変えた場合を検討する. 図 11 には $\kappa_{D}=2 \%$ とした場合の結果を示す. 図 9 と比較してもばらつ きの様子にはほとんど変化が無い、しかし，BRBの応力上昇が小さ いため接合部にすべりが生じる確率は $27.6 \%$ となり， $\kappa_{D}=3 \%$ の解析 よりも小さな値となっている. このため BRB の歪硬化は接合部にす ベり発生確率に影響を与える因子であると言える.

\section{3.3 構造特性係数の影響}

3.2 の解析で $D_{S}$ を 0.25 に変えた結果を図 12 に示す. $D_{S}$ が小さい ほどフレームが早い段階で塑性化するため全体に応答は大きく, フ レームのエネルギー吸収量は多くなる。しかし, すべり発生確率は $D_{S}$ よる影響はほとんど無く, すべりが発生するとどのモデルも同程 度に応答や損傷が増大寸る. この傾向は 9 モデルにおいて共通して おり，また， $D_{S}=0.45$ に設定した解析でも同様の結果であった。 寸
なわち， $D_{S}$ の值は接合部が剛と仮定して地震応答解析をした際の応 答には大きく影響するが，接合部にすべりが生じたときに応答の大 きさやエネルギー吸収がどれだけ増大寸るかにはあまり影響が無い. そのため接合部設計の観点で見れば， $D_{S}$ の異なる構造物でも同じ接 合部係数を設定すればよいと考えられる.

\subsubsection{BRB の降伏レベルの影響}

BRB の降伏レベルを 2 種類に変えた場合について比較する. 図 9 のモデルは 1 次設計レベルで塑性率 2 と設定したのに対して, 1 次 設計レベルまでBRB を弾性に保つように設計したモデルの解析結果 を図 13 に示す，図 9 よりも BRBのエネルギー吸収量が少なく，ま たすべりが発生しない場合の応答もやや大きい，これは BRB の降伏 レベルを小さく設定したほうが，早期から制振性能を十分に発揮で きることを意味している，そのかわり，BRBの歪が大きくなり歪硬 化の影響が大きくなる． BRB の最大歪の平均值は降伏レベルを小さ く設定した場合で $0.700 \%, 1$ 次レベルまで弾性の場合で $0.603 \%$ と なった。この解析ではすべての層の変形を等しいとみなしているが, 実際の建物では各層の変形が異なるため, BRB の最大歪が層ごとに 大小寸る．BRBの降伏レベルを小さく設定した場合, 丕硬化の影響 が大きいため，接合部にすべりが発生する確率が大きくなり制振性 能が低下寸るものも多く発生することになる．よって，BRB の降伏 レベルを小さくする場合には接合部の耐力を大きくする必要がある.

\section{4. 接合部係数の算定}

\section{1 接合部係数の決定に影響を及ぼすパラメータ}

3. で検証した内容を考慮しながら接合部係数の算定をする際には どのパラメータをもとに決定しなければならないかを検討する。図 14 には 9 モデルにおいて, 接合部係数を 0.05 ずつ変化させ, $Q_{J y}$ の 大きさを変えた場合にすべり発生確率と $E_{s F} / E_{d m}$ がどのように変化 するかを示す. $E_{s F} / E_{d m}$ については 1 万通りの平均值を示している. $\mathrm{BRB}$ には $\mathrm{SN} 400 \mathrm{~B}$ を用い, $\kappa_{D}=3 \%$, 摩擦面処理はブラストとして いる，接合部係数を大きくするに従いすべり発生確率は低下し，そ の結果フレームのエネルギー吸収量も低下して一定值に漸近する. エネルギー吸収の観点で見れば接合部係数が 1.4 程度よりも大きけ ればほぼ下限值に近づいており，十分に制振性能を発揮できる。固

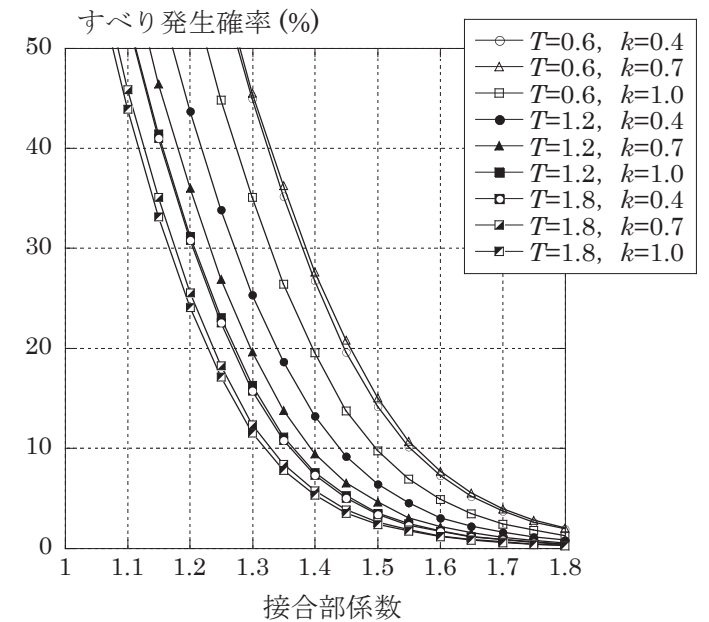

(a) 接合部係数とすべり発生確率の関係

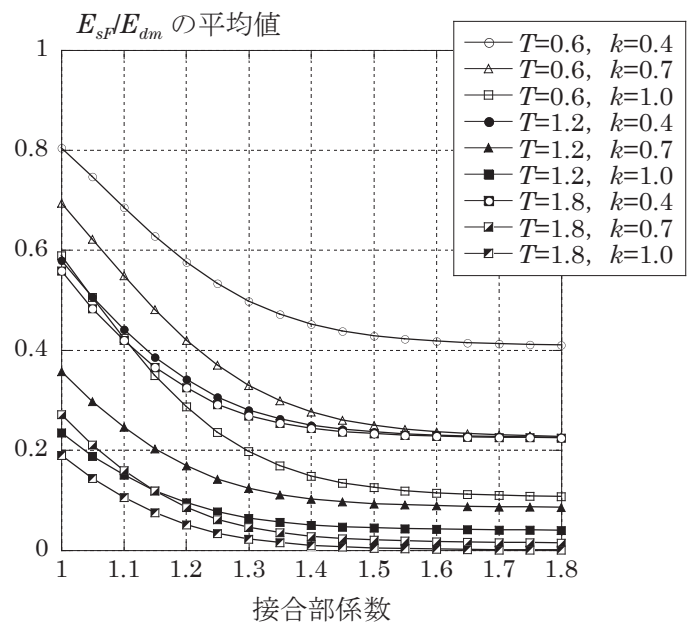

(b) 接合部係数と $E_{s F} / E_{d m}$ の平均值の関係

図 14 接合部係数とすべり発生確率, エネルギー吸収の関係 (9model, SN400B, 摩擦面ブラスト処理) 


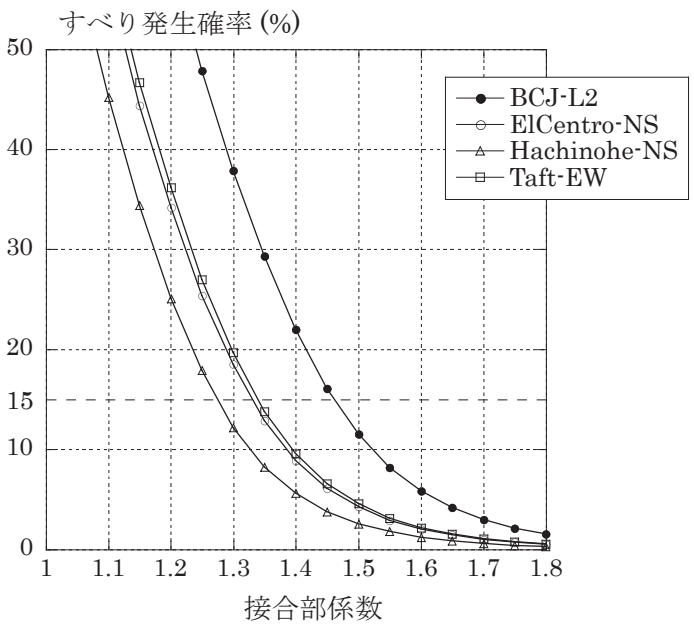

(a) 接合部係数とすべり発生確率の関係

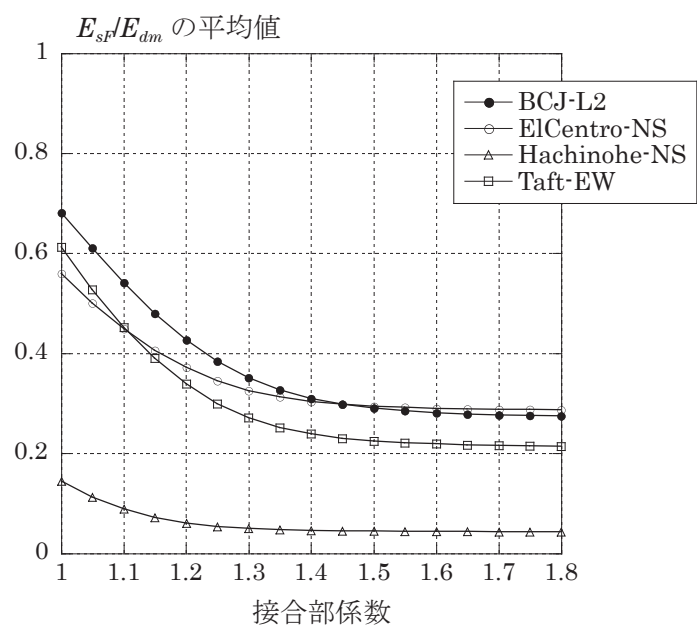

(b) 接合部係数と $E_{s F} / E_{d m}$ の平均值の関係

図 15 接合部係数とすべり発生確率，エネルギー吸収の関係 (4 地震波，SN400B，摩擦面ブラスト処理)

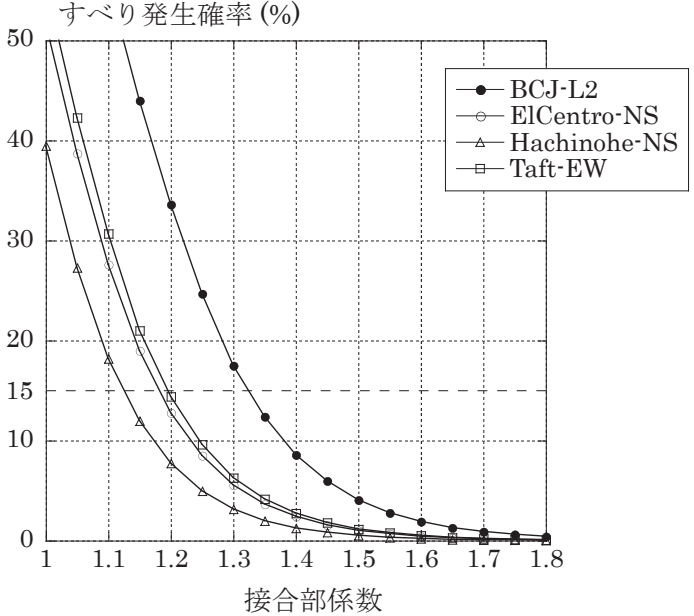

(a) 接合部係数とすべり発生確率の関係

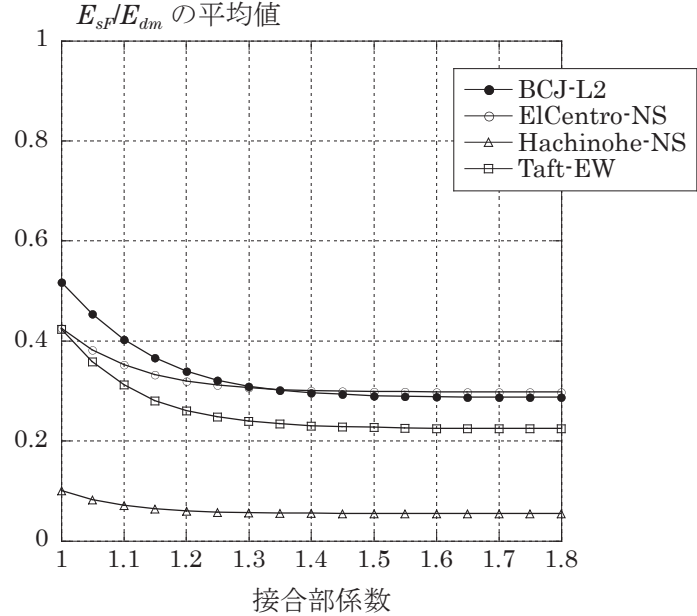

(b) 接合部係数と $E_{s I} / E_{d m}$ の平均值の関係

図 16 接合部係数とすべり発生確率，エネルギー吸収の関係（4 地震波，LY225，摩擦面ブラス卜処理）

有周期の異なる 3 種類のモデルは, それぞれフレームのエネルギー 吸収量は入力波との関係で異なるが，接合部係数の值による曲線の 傾きの変化や下限值に収束する接合部係数の值はいずれも共通して いる．建物の剛性比については図 14 からもわかるようにBRB を多 く含む建物は剛性比が大きくフレームのエネルギー吸収量が小さい 傾向がある。しかし，接合部に損傷が生じたときにフレームのエネ ルギー吸収量が増大する傾向は剛性比の違いによらずよく似ている. 以上より接合部係数の決定に影響を及ぼさないパラメータとして固 有周期，剛性比，構造特性係数が挙げられる。

一方, 接合部設計の際に考慮しなくてはならないパラメータを考 える．まず，降伏応力のばらつきが異なるため BRB 芯材の鋼種は考 慮しなくてはならない，また，歪硬化の影響も考慮する．文献 8)に よれば同じ鋼種でも座屈拘束方法によって歪硬化係数に多少の差が 見られ，引張側と圧縮側でも差があるが，大きめの $\kappa_{D}=3 \%$ として設 計しておけば接合部の耐力が不足することにはなりにくい. BRBの 降伏レベルについてみると BRB を 1 次設計レベルよりも早期に降 伏させる場合（ここでは塑性率 2）には歪硬化の影響から接合部の 耐力を大きくしなくてはならない. 最後に接合部の摩擦面処理につ いても考慮するとさらに精度の高い設定が可能であるが，一般的に
表 4 接合部係数の算定例

\begin{tabular}{|c|c|c|}
\hline BRB 鋼材 & すべり発生を防ぐ設計 & エネルギー吸収を確保する設計 \\
\hline SN400B & 1.50 & 1.45 \\
\hline LY225 & 1.35 & 1.30 \\
\hline
\end{tabular}

(1 次レベルで BRB 塑性率 2, 歪効果係数 $3 \%, \mathrm{BCJ}-\mathrm{L} 2$ の場合)

摩擦面処理によって接合部係数に異なる值を用いることはないので, ここではすべり係数の平均值が小さいブラスト処理面の值を用いて 設計する.

\section{2 接合部係数の算定例}

接合部係数の算定例を示寸，図 15 は BRB に SN400B を用いた場 合の 9 モデルの結果をまとめて示している. 接合部係数は 0.05 ごと に変化させており， 1 万通りずつ解析を行った 9 モデルの平均値に 標準偏差を加えた值を 1 本の線で示している．つまり図 14(a) の図 を元に図 15(a)の 1 本のラインを描いている．地震波には BCJ-L2 の他に最大速度を50kine で基準化した標準 3 波でも解析を行った. これらを比べると BCJ-L2 のほうが最大速度が大きいこともあり， すべり発生確率は最も大きな值となっている。そのため BCJ-L2 の 結果を元に接合部係数を考える. 仮に信頼性指標 1 を基準にす心゙り 
発生確率を $15 \%$ 以下に抑えることを目標とすれば接合部係数は 1.50 が必要である.

しかし，すべりが発生しても制振効果が保持され，変形が抑えら れれば若干の寸べりを許容することが可能である．変形の大きさは 地震波と固有周期の影響で值が変わりや寸く検討が難しいため，エ ネルギー吸収の観点から接合部係数を検討する. 図 15(b) に接合部 係数とフレームのエネルギー吸収の割合の関係を示す。縦軸は $E_{s F} /$ $E_{d m}$ の 1 万通りの平均值を 9 モデルで平均した值に標準偏差を加え たものである. すなわち, 図 14(b) の結果から図 15(b) の BCJ-L2 のラインが 1 本描けることになる. これを見ると, 接合部係数を大 きくするに従いフレームの損傷は低下し, 一定值に漸近することが わかる. 図 15(b) では接合部係数 1.3 から 1.4 程度以上ではほとんど 変わらない. したがって接合部係数は 1.4 以上で制振性能はほとん ど確保できており, 必要以上に大きい接合部係数を設定してもフレー ムの損傷はそれ以上軽減させることができないと言える.

LY225についても $\kappa_{D}=3 \%$, 摩擦面処理はブラストとして図 16 を 用いて同様に検討寸る。すべり発生確率を $15 \%$ 以下に抑えるには接 合部係数 1.35 程度が必要であるのに対し, エネルギー吸収量で見る と接合部係数 1.2 から 1.3 程度で十分に制振性能を確保したと言え る. LY225 で必要とされる接合部係数が SN400B の場合よりも小さ いのは LY225 の降伏応力のばらつきの範囲が $205-245\left(\mathrm{~N} / \mathrm{mm}^{2}\right)$ と 小さいためである. BCJ-L2 の結果からまとめると, 表 4 のように 接合部係数を決定できると考えられる。ここでのエネルギー吸収を 確保する設計は，接合部が岡の場合に比べて，フレームに入力する エネルギー増加量を 1 割以下に抑制するための接合部係数を設定し ている.ただし，この接合部係数は鋼材の降伏耐力が十分に大きい 場合を想定しており，接合部の降伏耐力がすべり耐力で決定される 場合の值である.

\section{5. 結論}

$\mathrm{BRB}$ の接合部必要耐力に影響を与える因子を明らかにし，接合部 係数を設定するため, 全ての層に BRB を含む構造物をパラメータの 影響をより明確に把握しやすい 1 質点系にモデル化して, 時刻歴応 答解析を行った。この結果から以下のような知見を得た。

(1) BRB の接合部係数を決定する際には, BRB の鋼種, 歪硬化係数, BRB の降伏レベルが大きく影響し，それ以外の建物の固有周期 や剛性比，構造特性係数の影響は小さいと考えられる.

（2）接合部にすべりが生じるか否かの観点では無く，フレームの損 傷を如何に軽減するかという観点で評価すれば，接合部係数を 小さく設定してもよいことがわかる．この方法により制振性能 を保証したより合理的な接合部設計が可能となる.

（3）このような考え方を適用し， 1 次設計レベルで塑性率 2 となる 設計の BRB に対し，芯材鋼種が SN400B，LY225 の場合につ いて接合部係数を示した.

本論文の検討では高次モードや架構の曲げ変形の影響は考慮して いない，その影響や，各層の BRB の配置が異なる場合については， 多質点系や骨組モデルでより詳細な解析が必要である.

\section{謝辞}

（株）NS ボルテン畑中清氏ならびに高力ボルト協会からは摩擦接
合部のすべり係数に関する貴重な実験データを提供して頂きました. また, 本研究の一部は 2009 年度鴻池奨学財団研究助成を受けました. ここに記して感謝の意を表します。

\section{参考文献}

1） 日本建築学会：鋼構造接合部設計指針，第 2 版， 2006 .

2）日本鋼構造協会編：履歷型ダンパー付骨組の地震応答性状と耐震設計法, 1998.9 .

3）日本免震構造協会編：パッシブ制振構造設計・施行マニュアル, 第 2 版, 2007.7.

4）建築研究所，日本鉄鋼連盟市場センター：「履歴型ダンパー付鋼構造骨組 の設計法」報告書, 2002.2 .

5）井上一朗，桑原進，多田元英，中島正愛：履歷型ダンパーを用いた架構 の地震応答と設計耐力, JSSC 鋼構造論文集, Vol.3, No.11, pp.65-77, 1996.9.

6) Specification for Structural Steel Buildings, ANSI/AISC 360-05, 2005.3.9.

7）辻岡静雄：ショットブラスト摩擦面を有する高力ボルト接合のす心゙り 荷重と履歴特性, 日本建築学会構造系論文集, 第 471 号, pp.173-179, 1995.5.

8）建築研究所監修: 鋼構造建築物へのエネルギー法活用マニュアル，技報堂 出版, 2008.

9）志村保美，高田啓一，作本好文，塩飽豊明，藤沢一善 : SN 鋼の機械的性 質に関する統計調査, 日本建築学会大会学術講演梗概集 (東海), C-1, 構 造III, pp.535-536, 2003.9.

10）日本建築学会・材料施工委員会，鉄骨工事運営委員会 : 建築鉄骨工事の 新たな課題への取り組み鉄骨工事運営委員会調査研究報告会資料集, 2010.5

11）日本建築学会 : 鋼構造限界状態設計指針・同解説，第 3 版，2010.2.

（2010年 5 月10日原稿受理，2010年12月28日採用決定） 